\title{
Efektifitas Pemberian Waktu Bebas Bermain Untuk Meningkatkan Mood Positive Sebelum Kegiatan Belajar Mengajar Bagi Siswa Sekolah Dasar
}

\author{
Siti Pangestutik, Musyarofah, H dan Rahmawati, R.A. \\ Universitas Negeri Semarang \\ Email : pangestutik.siti10@gmail.com
}

\begin{abstract}
.
This research's goal to know the effectiveness of giving free time playing to improve positive mood of student. The subject in this research is student in third grade elementary school which amount 30 students. The design which is used is one group pretest posttest design experiment, with pretest and posttest which is done in three days continuously. Treatment that is given 30minute playing time divided into two sessions, students are free to play by choosing the games provided and video playback on learning. The result of data analysis is obtained by using Paired Sample T-Test is t1 -0,722 with sign 0,476; T2 -0.403 with sign 0.690; T3 -0.626 with sign 0.536 ( $p>0.05)$, it can be concluded that in this study there is no difference in positive mood before and after students given free play time treatment. This happens because the subjects involved in the research have been accustomed to being given free time playing. Therefore, free time playing is not effective to improve students' positive mood in this school. This is evidenced by the absence of significant positive mood score between before (pretest 1 , 2 and 3) after posttest 1,2 and 3 giving free time treatment.
\end{abstract}

Keywords: giving free time playing, positive mood, student.

\section{PENDAHULUAN}

Tujuan anak datang ke sekolah adalah mencari ilmu. Dalam proses belajar, anak diharapkan siap dalam aspek kognitif, afektif maupun psikomotor. Dengan demikian, materi yang disampaikan guru dapat dipahami anak dengan baik. Padahal, anak berangkat dari rumah ke sekolah dengan latar belakang kondisi dan situasi yang berbeda. Misalnya: anak berangkat ke sekolah dengan terpaksa, anak merasa jengkel dengan orang tua karena tidak dibangunkan, anak tidak mau mandi sebelum ke sekolah, susah bangun, beradu mulut dengan saudara, ada bendanya yang tertinggal dan sebagainya.

Terjadinya ha-hal demikian secara tidak langsung berpotensi menimbulkan emosi negative dalam diri anak, yang nantinya dibawa hingga ia berada di lingkungan sekolah. Kondisi ini dapat memperburuk keadaan anak ketika anak tidak dapat menerima materi dari guru. Oleh sebab itu, kondisi mood anak ketika disekolah akan mempengaruhi kesiapan anak dalam belajar.

Davine dkk (2010: 6) menjelaskan emosi terjadi sebagai akibat dari suatu kejadian yang terjadi pada konteks terntentu. Emosi negative secara tidak langsung berhubungan dengan timbulnya mood pada diri individu. Davine dkk (2010: 8) juga mengungkapkan bahwa emosi dapat berubah menjadi mood apabila kehilangan objek yang memunculkan emosi dan bertahan dalam waktu yang lama (jam atau hari), begitu juga mood dapat berubah menjadi emosi apabila 
memiliki objek emosi dan memiliki kecenderungan untuk memunculkan perilaku dalam waktu yang singkat. Suasana hati atau mood merupakan gambaran situasi batin atau keadaan hati yang hanya bisa dimengerti dengan pasti oleh masing-masing individu yang mengalami (Wiyanto dkk, 2006:107). Sementara Ekkekakis (2012: 324) membagi mood kedalam dua kelompok, yaitu positive mood dan negative mood.

Salah satu upaya untuk menangani emosi negative sekaligus untuk menetralisir negative mood yang ada dalam diri anak dapat dilakukan dengan cara bermain. Bermain adalah setiap kegiatan yang dilakukan untuk kesenangan yang ditimbulkannya tanpa mempertimbangkan hasil akhir (Hurlock, 1987: 320). Piaget dalam Patmonodewo (2000: 108) menerangkan bahwa permainan pada akhir masa anak-anak biasanya memiliki karakteristik logis, misalnya: adanya aturan-aturan tertentu dan strukturnya jelas. Permainan anak di usia 10 tahun bersifat persaingan dengan pokok perhatian pada ketrampilan dan keunggulan serta tidak hanya memberikan kesenangan. Bermain bagi anak usia enam sampai dengan 12 tahun merupakan cara efektif untuk belajar (Hurlock, 2002: 161).

Pemberian waktu bebas bermain sebelum kegiatan belajar mengajar dimulai merupakan implikasi dari proses bermain itu sendiri. Profesor di Toronto Ryerson University, Raktim Mitra, (2016) mengungkapkan bahwa secara teoretis, kebebasan yang diberikan orang tuanya menciptakan peluang bagi mereka melakukan hal spontan yang berkontribusi pada aktivitas fisiknya. Sehingga, melalui kegiatan bermain diharapkan dapat menumbuhkan positive mood pada anak, sehingga setelah bermain perasaan anak menjadi bahagia.

$\mathrm{O}_{1} \rightarrow \mathrm{X} \rightarrow \mathrm{O}$,
Seattle Children Reseach Institute mengatakan bahwa anak-anak dianjurkan untuk mendapatkan 120 menit aktivitas fisik per hari. Karena hasil penelitian di Kanada, sebanyak $35 \%$ orang tua atau pengasuh melaporkan mereka tidak pernah membiarkan anak-anaknya pergi keluar sendiri ataupun hanya dengan temantemannya. Hanya $16 \%$ anak yang sering atau selalu diizinkan untuk melakukan perjalanan mandiri. Anak-anak yang diizinkan untuk pergi keluar dan menjelajah sendiri atau bersama temantemannya selama beberapa saat, $19 \%$ lebih aktif secara fisik daripada anak-anak yang selalu diawasi. Mood juga berpotensi dapat mempengaruhi cara seseorang merespon rangsangan. Misalnya, mood yang tertekan cenderung merespon negatif, sedangkan mood senang cenderung merespon dengan semangat.

Berdasarkan fenomena diatas, bahwa masih terdapat masalah mengenai kondisi mood siswa, dengan demikian penulis tertarik untuk melakukan penelitian mengenai efektivitas pemberian waktu bebas bermain untuk meningkatkan positive mood pada siswa sebelum belajar mengajar dimulai.

\section{METODE}

Dalam penelitian ini, penulis menggunakan jenis quasi eksperimen dengan desain penelitian one pretest posttest design dengan pretest dan posttest dilakukan sebanyak tiga kali dalam tiga hari berturut-turut. Dalam rancangan ini subjek yang dilibatkan yaitu siswa kelas tiga Sekolah Dasar. Skema rancangan dapat digambarkan sebagai berikut : 
Keterangan:

$\mathrm{O}_{1}$ : Pengukuran awal (pre-test)

$\mathrm{X}$ : Perlakuan (Treatment)

$\mathrm{O}_{2}$ : pengukuran akhir (post-test)

Subjek penelitian ini adalah siswa kelas tiga Sekolah Dasar. Subjek yang dilibatkan sebanyak 30 orang. Alat pengumpulan data berupa skala mood. Skala dalam penelitian ini bentuknya tertutup, tiap butirnya disediakan hanya dengan dua jawaban yaitu Ya dan Tidak. Subjek diminta untuk memilih salah satu dari dua kemungkinan jawaban. Penilaian favorable untuk jawaban $\mathrm{Ya}=1$, Tidak $=$ 0 , sedangkan penilaian untuk butir unfavorable jawaban $\mathrm{Ya}=0$ dan Tidak $=1$.

Pengaruh perlakuan dapat dilihat dari perbandingan hasil pretest dan posttest subjek penelitian. Apabila skor pretest lebih kecil secara signifikan daripada skor posttest maka, dapat disimpulkan bahwa pemberian waktu bebas bermain efektif untuk meningkatkan positive mood siswa sebelum kegiatan belajar mengajar dimulai. Penelitian ini menggunakan teknik analisis data parametrik dikarenakan setelah dilakukan pengoahan data melalui metode statisktik, data yang dihasilkan berdistribusi normal dan homogen. Sehingga teknik analisis data yang digunakan dalam penelitian ini adalah dengan uji paired sample t-test.

\section{HASIL}

Dalam penelitian ini, metode kategorisasi yang digunakan yaitu kategorisasi jenjang (Azwar, 2011:108). Berdasarkan perhitungan, maka dapat dibuat kategorisasi sebagai berikut:

Table 1. Kategorisasi Positive Mood

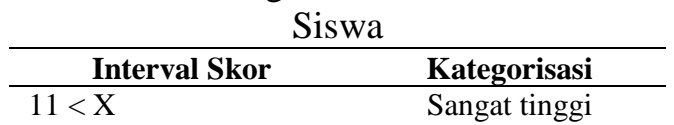

\begin{tabular}{lc}
$9<X \leq 11$ & Tinggi \\
$7<X \leq 9$ & Sedang \\
$5<X \leq 7$ & Rendah \\
$X \leq 5$ & Sangat rendah \\
\hline
\end{tabular}

Adapun gambaran mengenai positive mood mood siswa sebelum perlakuan (pretest 1) disajikan dalam tabel 2.

Tabel 2. Gambaran Positive Mood Siswa Sebelum Perlakuan (pretest)

\begin{tabular}{clllll}
\hline \multirow{2}{*}{$\begin{array}{c}\text { Ha- } \\
\text { ri }\end{array}$} & $\begin{array}{l}\text { Sngt } \\
\text { tinggi }\end{array}$ & $\begin{array}{l}\text { Ting } \\
\text {-gi }\end{array}$ & $\begin{array}{l}\text { Se- } \\
\text { dang }\end{array}$ & $\begin{array}{l}\text { Ren- } \\
\text { dah }\end{array}$ & $\begin{array}{l}\text { Sngt } \\
\text { ren- } \\
\text { dah }\end{array}$ \\
\hline 1 & $20 \%$ & $50 \%$ & $13,3 \%$ & $13,3 \%$ & $3,3 \%$ \\
& $(6)$ & $(15)$ & $(4)$ & $(4)$ & $(1)$ \\
\hline 2 & 26,7 & 46,7 & $16,8 \%$ & $6,7 \%$ & $3,3 \%$ \\
& $\%$ & $\%$ & $(5)$ & $(2)$ & $(1)$ \\
& $(8)$ & $(14)$ & & & \\
\hline 3 & 16,7 & 63,3 & $6,7 \%$ & $13,3 \%$ & \\
& $\%$ & $\%$ & $(2)$ & $(4)$ & - \\
& $(5)$ & $(19)$ & & & \\
\hline
\end{tabular}

Berdasarkan tabel tersebut, hasil pengukuran pada hari pertama dapat dilihat bahwa sebagian besar responden yang mengikuti perlakuan pemberian waktu bebas bermain tergolong rata-rata memiliki tingkat positive mood yang berkategori tinggi. Sementara hasil pengukuran pada hari kedua dapat dilihat bahwa sebagian besar responden yang mengikuti perlakuan pemberian waktu bebas bermain tergolong rata-rata memiliki tingkat positive mood yang berkategori tinggi. Sendangkan hasil pengukuran pada hari ketiga dapat dilihat bahwa tidak ada responden yang memiliki kategori positive mood sangat rendah, serta rata-rata responden yang mengikuti perlakuan pemberian waktu bebas bermain tergolong rata-rata memiliki tingkat positive mood yang berkategori tinggi. Oleh karena itu dapat disimpulkan bahwa responden yang terlibat dalam penelitian pemberian waktu bebas bermain tergolong memiliki tingkat positive mood yang berkategori tinggi. 
Sedangkan gambaran mengenai positive mood setelah perlakuan pemberian waktu bebas bermain (posttest) disajikan daam tabel 3 .

Table 3. Gambaran Positive Mood Siswa Sesudah Perlakuan (posttest)

\begin{tabular}{clllll}
\hline & \multicolumn{5}{c}{ Kategorisasi } \\
\cline { 2 - 6 } $\begin{array}{c}\text { Ha } \\
\text { ri }\end{array}$ & $\begin{array}{l}\text { Sngt } \\
\text { tinggi }\end{array}$ & $\begin{array}{l}\text { Ting- } \\
\text { gi }\end{array}$ & $\begin{array}{l}\text { Se- } \\
\text { dang }\end{array}$ & $\begin{array}{l}\text { Ren- } \\
\text { dah }\end{array}$ & $\begin{array}{l}\text { Sngt } \\
\text { ren- } \\
\text { dah }\end{array}$ \\
\hline 1 & $16,7 \%$ & $60 \%$ & $10 \%$ & $13,3 \%$ & - \\
& $(5)$ & $(18)$ & $(3)$ & $(4)$ & - \\
\hline 2 & $20 \%$ & 53,3 & 23,3 & $3,3 \%$ & \\
& $(6)$ & $\%$ & $\%$ & $(1)$ & - \\
& & $(16)$ & $(7)$ & & \\
\hline 3 & $16,7 \%$ & 66,7 & $10 \%$ & $3,3 \%$ & $3,3 \%$ \\
& $(5)$ & $\%$ & $(3)$ & $(1)$ & $(1)$ \\
\hline
\end{tabular}

Berdasarkan hasill posttest diperoleh peningkatan positive mood pada siswa dalam kategori sangat rendah 3,34\% menjadi $0 \%$. Pada kategori sedang mengalami penurunan dari 13,33\% menjadi $10 \%$ dan pada kategori tinggi mengalami kenaikan dari $50 \%$ menjadi $60 \%$. Sementara hasil posttest hari kedua terjadi peningkatan mood pada siswa, dari $3,34 \%$ menjadi $0 \%$ dalam kategori sangat rendah. Terjadi penurunan dari $6,67 \%$ menjadi 3,34\% dalam kategori rendah. Dan terjadi peningkatan positive mood dalam kategori sedang yaitu dari $16,67 \%$ menjadi $23,33 \%$. Begitu juga dalam kategori tinggi mengalami peningkatan, dari $46,67 \%$ menjadi 53,335.

Hasil posttest hari ketiga juga menunjukan peningkatan yakni, hal ini ditunjukan pada siswa dalam kategori rendah semula $13,33 \%$ menjadi $3,33 \%$, dalam kategori sedang dari $6,67 \%$ menjadi $10 \%$ serta dalam kategori tinggi dari $63,33 \%$ menjadi $66,67 \%$.

Berdasarkan data pada tabel 4 (lampiran), tampak pretest 1 dengan posttest 1 pada hari pertama bahwa sebanyak 10 orang yang mengalami perubahan dalam hal kategori yakni sebanyak 2 orang mengalami perubahan kategori dari sangat tinggi ke tinggi, 2 orang dari kategori sedang ke tinggi, 1 orang dari kategori sedang ke rendah, 2 orang dari tinggi ke sedang, 2 orang dari rendah ke tinggi dan 1 orang mengalami perubahan dari kategori tinggi ke sangat tinggi.

Dari pretest 2 dengan posttest 2 pada hari kedua diperoleh hasil bahwa sebanyak 5 orang yang mengalami perubahan dalam hal kategori yakni sebanyak 2 orang mengalami perubahan kategori dari sangat tinggi ke tinggi, 1 orang dari kategori sedang ke tinggi, 1 orang dari kategori sangat rendah ke sedang, 1 orang dari tinggi ke sedang.

Dari pretest 3 dengan posttest 3 pada hari ketiga diperoleh hasil bahwa sebanyak 6 orang yang mengalami perubahan dalam hal kategori yakni sebanyak 1 orang mengalami perubahan kategori dari rendah ke sangat rendah, 2 orang mengalami perubahan dari kategori rendah ke sedang, 2 orang dari kategori sedang ke tinggi, 1 orang mengalami perubahan dari tinggi ke sedang,

Analisis data dilakukan untuk menjawab permasalahan yang telah dirumuskan. Pada Bab I terdahulu telah dirumuskan permasalahan apakah pemberian waktu bebas bermain dapat meningktkan positive mood pada siswa sebelum kegiatan belajar mengajar dimulai. Adapun hipotesis kerja (Ha) dalam penelitian ini adalah ada perbedaan tingkat positive mood pada siswa Sekolah Dasar, tingkat positive mood siswa Sekolah Dasar sesudah pemberian waktu bebas bermain lebih tinggi sebelum pemberian waktu bebas bermain. Pengujian hipotesis penelitian ini menggunakan analisis uji Paired Sample T-Test.

Berdasarkan hasil analisis diketahui perbandingan pretest 1 dengan 
pretest 2 dari 30 responden, 10 orang bertanda positif atau dapat dikatakan bahwa hasil positive mood meningkat, 6 orang bertanda negartif. Pretest 2 dengan pretest 3 dari 30 responden, 5 bertanda positif dan 5 negatif. Dari pretest 1 dengan pretest 3 dari 30 responden, 9 bertanda positif dan 9 bertanda negatif. Hasil uji paired sample t-test pada pretest 1 diketahui nilai $t_{1}-1,408$ dengan sign 0,1706 ; pretest kedua diketahui $\mathrm{t}_{2}-0,112$ dengan sign 0,912 ; pretest ketiga diketahui $\mathrm{t}_{3}-1,418$ dengan sign 0,167 dengan demikian ( $p$ > 0.05), maka dapat diartikan bahwa tidak ada perbedaan yang signifikan antara hasil pretest 1 , pretest 2 , dan pretest 3. Sedangkan hasil uji paired sample t-test pada posttest 1 diketahui nilai $\mathrm{t}_{1}-1,000$ dengan sign 0,326 ; posttest kedua diketahui $\mathrm{t}_{2}-0,130$ dengan sign 0,897 ; posttest ketiga diketahui $\mathrm{t}_{3}-1,017$ dengan sign 0,318 dengan demikian ( $\mathrm{p}>0.05$ ), maka dapat diartikan bahwa tidak ada perbedaan yang signifikan antara hasil posttest 1 , posttest 2 , dan posttest 3

Tabel 5. Hasil Paired Sample T-Test

\begin{tabular}{|c|c|c|c|c|c|}
\hline $\begin{array}{l}\mathrm{Ha} \\
\text {-ri }\end{array}$ & $\begin{array}{l}\text { Keteran } \\
\text { gan }\end{array}$ & Mean & $\begin{array}{l}\text { Kore } \\
\text { lasi }\end{array}$ & $\mathrm{t}$ & $\begin{array}{l}\text { Sig } 2 \\
\text { Sisi) }\end{array}$ \\
\hline \multirow[t]{2}{*}{1} & Pre test & 9,8333 & \multirow[b]{2}{*}{0,67} & & \multirow[b]{2}{*}{0,46} \\
\hline & $\begin{array}{l}\text { Post } \\
\text { test }\end{array}$ & 10,0333 & & 0,722 & \\
\hline \multirow[t]{2}{*}{2} & Pre test & 10,2000 & \multirow[b]{2}{*}{0,88} & & \multirow[b]{2}{*}{0,690} \\
\hline & $\begin{array}{l}\text { Post } \\
\text { test }\end{array}$ & 10,2667 & & 0,403 & \\
\hline \multirow[t]{2}{*}{3} & Pre test & 10,2333 & \multirow[b]{2}{*}{0,93} & & \multirow[b]{2}{*}{0,536} \\
\hline & $\begin{array}{l}\text { Post } \\
\text { test }\end{array}$ & 10,3000 & & $\overline{0}, 626$ & \\
\hline
\end{tabular}

Berdasarkan hasil analisis data antara pretest 1 dengan posttest 1 diperoleh $\mathrm{t}_{1}-0,722$ dengan sign 0,476 dan nilai mean 9,8333 dan 10,0333; pretest 2 dengan posttest 2 diperoleh $\mathrm{t}_{2}-0,403$ dengan sign 0,690 dan nilai mean 10,2000 dan 10,2667 ; pretest 3 dengan posttest 3 diperoleh $\mathrm{t}_{3}$ 0,626 dengan sign 0,536 dengan mean
10,2333 dan 10,3000. Dengan demikian (p $>0.05$ ), maka dapat disimpulkan bahwa dalam penelitian ini tidak ada perbedaan positive mood siswa sebelum dan sesudah diberikan perlakuan waktu bebas bermain.

\section{SIMPULAN}

Berdasarkan pembahasan diatas, maka dapat diambil kesimpulan bahwa pemberian waktu bebas bermain tidak efektif untuk meningkatkan positive mood pada siswa. Simpulan diatas dimunculkan berdasarkan tidak adanya perbedaan secara signifikan tingkat positive mood pada anak antara sebelum (pretest) dan sesudah (posttest) pemberian waktu bebas bermain pada siswa Sekolah Dasar.

Adapun saran yang dapat penulis sampaikan antara lain:

1. Bagi pihak Sekolah Dasar

Bagi pendidik yang terlibat dalam kegiatan belajar mengajar diharapkan membatasi waktu bebas bermain bagi siswa. Misalnya: guru masuk kelas tepat waktu, memberikan materi sesuai jadwal, meningkatkan disiplin anak dalam belajar.

2. Bagi peneliti selanjutnya

Bagi peeliti yang hendak melakukan penelitian yang sama, sebaiknya memilih subjek penelitian yang memiliki kondisi mood tergolong negatif atau negative mood. Selain itu, peneliti selanjutnya diharapkan memberikan permainan yang lebih bervariasi agar menarik perhatian anak sehingga kondisi mood meningkat.

\section{DAFTAR PUSTAKA}

Azwar, S. 2010. Penyusunan Skala Psikologi. Yogyakarta: Pustaka Pelajar.

2011. Metode Penelitian. Yogyakarta: Pustaka Pelajar. 
Devine, Eric G et al. (2010). Module 9 : Mood Management

Comprehensive Addiction

Treatment. Boston Center for Treatment Development and Training.

Ekkekakis, P. (2012). Affect, Mood, and Emotion. In G.Tenenbaum, R.C. Eklund \& A. Kamata (Eds). Measurement in support and excercise psychology, 321-332. Iowa State University.
Hurlock. E. B. (1987). Perkembangan Anak. Jakarta : Erlangga.

Hurlock, E.B (2002). Psikologi Perkembangan Edisi Lima. Erlanga: Jakarta.

Patmonodewo, Soemiarti. 2000. Pendidikan Anak Prasekolah. Jakarta : Rineka Cipta.

Wiyanto dkk. (2006). Mampu Berbahasa Indonesia. Jakarta : Grasindo. 


\section{Lampiran}

Table 4. Gambaran Positive Mood Siswa

\begin{tabular}{|c|c|c|c|c|c|c|}
\hline \multirow{2}{*}{ Nama } & \multicolumn{2}{|c|}{ Hari ke-1 } & \multicolumn{2}{|c|}{ Hari ke-2 } & \multicolumn{2}{|c|}{ Hari ke-3 } \\
\hline & pre 1 & post 1 & Pre 2 & Post 2 & Pre 3 & Post 3 \\
\hline $\mathrm{AF}$ & 11 & 11 & 11 & 11 & 11 & 11 \\
\hline RK & 11 & 11 & 11 & 11 & 11 & 11 \\
\hline AI & 7 & 6 & 7 & 8 & 11 & 10 \\
\hline $\mathrm{AY}$ & 7 & 7 & 12 & 11 & 6 & 5 \\
\hline FZ & 7 & 6 & 9 & 9 & 10 & 11 \\
\hline FL & 12 & 11 & 10 & 10 & 11 & 11 \\
\hline $\mathrm{AL}$ & 10 & 10 & 9 & 9 & 10 & 10 \\
\hline ST & 11 & 11 & 11 & 10 & 10 & 11 \\
\hline FR & 8 & 10 & 9 & 10 & 11 & 10 \\
\hline $\mathrm{AH}$ & 8 & 8 & 9 & 9 & 7 & 8 \\
\hline $\mathrm{OC}$ & 10 & 10 & 10 & 10 & 9 & 10 \\
\hline KS & 9 & 7 & 7 & 7 & 7 & 8 \\
\hline $\mathrm{NF}$ & 10 & 10 & 10 & 10 & 10 & 10 \\
\hline DH & 10 & 9 & 11 & 11 & 11 & 11 \\
\hline $\mathrm{AD}$ & 10 & 10 & 10 & 11 & 10 & 10 \\
\hline $\mathrm{CH}$ & 11 & 11 & 11 & 11 & 11 & 11 \\
\hline VI & 13 & 12 & 13 & 13 & 13 & 13 \\
\hline $\mathrm{AM}$ & 10 & 11 & 12 & 12 & 12 & 12 \\
\hline AN & 5 & 10 & 4 & 8 & 7 & 7 \\
\hline SY & 10 & 10 & 10 & 10 & 10 & 10 \\
\hline $\mathrm{AD}$ & 12 & 11 & 11 & 11 & 11 & 11 \\
\hline NF & 12 & 12 & 12 & 12 & 12 & 12 \\
\hline AT & 11 & 10 & 10 & 10 & 10 & 10 \\
\hline LI & 12 & 12 & 12 & 12 & 12 & 12 \\
\hline VS & 10 & 9 & 10 & 9 & 10 & 9 \\
\hline GH & 11 & 11 & 12 & 11 & 11 & 11 \\
\hline DP & 8 & 11 & 11 & 10 & 11 & 11 \\
\hline BG & 12 & 12 & 12 & 12 & 11 & 11 \\
\hline NR & 6 & 10 & 8 & 8 & 9 & 10 \\
\hline $\mathrm{AK}$ & 11 & 12 & 12 & 12 & 12 & 12 \\
\hline
\end{tabular}

